\title{
Dyschromatosis Universalis Hereditaria with Renal Failure
}

\author{
Salinee Rojhirunsakool Vasanop Vachiramon \\ Division of Dermatology, Department of Medicine, Faculty of Medicine, Ramathibodi \\ Hospital, Mahidol University, Bangkok, Thailand
}

\section{Key Words}

Dyschromatosis - Dyschromatosis universalis hereditaria - Dyspigmentation · End-stage renal disease $\cdot$ Renal failure

\begin{abstract}
Dyschromatosis universalis hereditaria (DUH) is a rare autosomal dominant inherited dermatosis which usually appears during childhood and is characterized by dyspigmentation, with both hypopigmented and hyperpigmented macules. We report a case of DUH with unexplained childhood-onset renal failure. The association between DUH and renal failure is yet to be proven by further studies.

(c) 2015 S. Karger AG, Basel
\end{abstract}

\section{Case Report}

A 16-year-old male presented with asymptomatic, slowly progressive abnormality of skin color, beginning when he was 1 year old. The lesions were first noticed on his chest and back, and subsequently involved his entire body except the palms and soles. At the age of 14, he had acute febrile illness followed by asymptomatic gross hematuria. The gross hematuria resolved within a couple of weeks, although it recurred intermittently. His renal function gradually deteriorated, eventually becoming end-stage renal disease. The definitive cause of renal failure could not be determined because of late presentation of the patient. A presumptive diagnosis of IgA nephropathy was made according to the clinical presentation. He currently requires renal dialysis and is awaiting kidney transplantation. He denied photosensitivity and previous exposure to arsenic or herbal medication. The patient and his family also denied a history of skin cancers. Many of his family members have similar skin dyspigmentation, as shown in the family pedigree (fig. 1). The onset of lesions in all involved members 
Rojhirunsakool and Vachiramon: Dyschromatosis Universalis Hereditaria with Renal Failure

occurred in childhood, as in our patient. There was no family history suggestive of renal disease.

Physical examination revealed generalized symmetrical hypopigmented and hyperpigmented macules, varying from 2 to $5 \mathrm{~mm}$ in size, on the face, trunk, extremities and dorsum of both hands and feet, sparing the palms and soles (fig. 2, fig. 3). There was no abnormality of oral mucosa or nails. Abdominal examination was normal. No mass could be palpated by bimanual palpation. Neurological examination was also normal.

\section{Discussion}

Dyschromatosis universalis hereditaria (DUH) is a rare inherited dyschromatosis, characterized by the appearance of both hypopigmented and hyperpigmented macules that can involve almost all parts of the body. The disease is usually autosomal dominant inheritance, with a few autosomal recessive and sporadic cases reported. Recently, a mutation in the $A B C B 6$ gene was identified as the pathologic gene in DUH. However, not all DUH patients have the $A B C B 6$ mutation. It is possible that DUH is a disease of genetic heterogeneity [1-3].

The main feature of DUH is a mixture of hypopigmented and hyperpigmented macules, distributed symmetrically. The lesions can occur anywhere on the body, but rarely involve the palms and soles. Facial lesions are found in approximately $50 \%$ of individuals. The lesions usually appear in infancy or early childhood and stop spreading before adolescence, after which the lesions will last for life [4-6]. The differential diagnoses of DUH are shown in table 1. Except for skin lesions, there is no other common associated condition in DUH; however, there have been various reports of an association with short stature and high-tone deafness, seizure, mental retardation, hair and nail abnormalities, ocular abnormalities and thrombocytopenia [4, 6-8]. Still, most DUH patients do not show any association. Furthermore, there have been no reports of malignant transformation of the lesions in DUH patients.

Histologically, hyperpigmented lesions of DUH contain more melanin than either normal or hypopigmented macules. In both hypopigmented and hyperpigmented lesions, melanocytes are found in normal number. Based on electron microscopic examination, a difference in the amount of fully melanized melanosomes in hypopigmented and hyperpigmented lesions was found. However, there was no difference in melanocyte number and tyrosinase activity. Therefore, DUH is not a disorder of melanocytes, but rather a defect of melanosome synthesis or transport $[9,10]$.

A definitive treatment has not been established for DUH. In most cases, patient education and reassurance are recommended. Although in a recent report hyperpigmented macules were successfully treated with a Q-switched alexandrite laser, longer follow-up of the result is needed [11]. In the present case, cosmetic appearance is not a concern. However, since the patient is scheduled for kidney transplantation, there is a question of malignant transformation of his skin lesions. In our opinion, the lesions of DUH should not increase the risk of skin cancer for the average transplant patient, and indeed DUH has thus far never been associated with such a risk. However, since the pathogenesis of DUH still remains to be elucidated, we plan to follow up on the patient's condition in the future.

Our patient demonstrates the typical cutaneous presentation and inheritance in his family. His family tree clearly demonstrates an autosomal dominant pattern of the disease. Thus, our case gives further support to the previous evidence that DUH is an autosomal dominant disease. Furthermore renal failure, which occurred in our case, has never been previously reported in the literature. Renal involvement may be another internal organ manifestation in patients with DUH. However, renal biopsy was not performed due to the late presentation of 
Rojhirunsakool and Vachiramon: Dyschromatosis Universalis Hereditaria with Renal Failure

renal failure in this case. Therefore, whether the occurrence of renal failure is a true association or a coincidence remains inconclusive. Further study is needed to prove this association.

\section{Disclosure Statement}

The authors declare that they have no conflict of interest and that they received no funding or support.

\section{References}

1 Liu H, Li Y, Hung KKH, Wang N, Wang C, Chen X, Sheng D, Fu X, See K, Foo JN, Low H, Liany H, Irwan ID, Liu J, Yang B, Chen M, Yu Y, Yu G, Niu G, You J, Zhou Y, Ma S, Wang T, Yan X, Goh BK, Common JEA, Lane BE, Sun Y, Zhou G, Lu X, Wang Z, Tian H, Cao Y, Chen S, Liu Q, Liu J, Zhang F: Genome-wide linkage, exome sequencing and functional analyses identify $A B C B 6$ as the pathogenic gene of dyschromatosis universalis hereditaria. PLoS One 2014;9:e87250.

-2 Cui YX, Xia XY, Zhou Y, Gao L, Shang XJ, Ni T, Wang WP, Fan XB, Yin HL, Jiang SJ, Yao B, Hu YA, Wang G, Li XJ: Novel mutations of $A B C B 6$ associated with autosomal dominant dyschromatosis universalis hereditaria. PLoS One 2013;8:e79808.

-3 Stuhrmann M, Hennies HC, Bukhari IA, Brakensiek K, Nürnberg G, Becker C, Huebener J, Miranda MC, Frye-Boukhriss H, Knothe S, Schmidtke J, El-Harith EH: Dyschromatosis universalis hereditaria: evidence for autosomal recessive inheritance and identification of a new locus on chromosome 12q21-q23. Clin Genet 2008;73:566-572.

4 Al Hawsawi K, Al Aboud K, Ramesh V, Al Aboud D: Dyschromatosis universalis hereditaria: report of a case and review of the literature. Pediatr Dermatol 2002;19:523-526.

5 Wu CY, Huang WH: Two Taiwanese siblings with dyschromatosis universalis hereditaria. Clin Exp Dermatol 2009;34:e666-e669.

6 Vachiramon V, Thadanipon K, Chanprapaph K: Infancy- and childhood-onset dyschromatoses. Clin Exp Dermatol 2011;36:833-838.

7 Rycroft RJG, Calnan CD, Wells RS: Universal dyschromatosis, small stature and high-tone deafness. Clin Exp Dermatol 1977;2:45-48.

8 Pirasath S, Sundaresan T, Tamilvannan T: Thrombocytopenia in dyschromatosis universalis hereditaria. Ceylon Med J 2012;57:124-125.

-9 Nuber UA, Tinschert S, Mundlos S, Hauber I: Dyschromatosis universalis hereditaria: familial case and ultrastructural skin investigation. Am J Med Genet A 2004;125A:261-266.

10 Kim NS, Im S, Kim SC: Dyschromatosis universalis hereditaria: an electron microscopic examination. J Dermatol 1997;24:161-164.

11 Nogita T, Mitsuhashi Y, Takeo C, Tsuboi R: Removal of facial and labial lentigines in dyschromatosis universalis hereditaria with a Q-switched alexandrite laser. J Am Acad Dermatol 2011;65:e61-e63. 


\section{Case Reports in Dermatology}

\begin{tabular}{l|l}
\hline Case Rep Dermatol 2015;7:51-55 \\
\hline DOI: $10.1159 / 000381174$ & $\begin{array}{l}\text { C } 2015 \text { S. Karger AG, Basel } \\
\text { www.karger.com/cde }\end{array}$ \\
\hline
\end{tabular}

Rojhirunsakool and Vachiramon: Dyschromatosis Universalis Hereditaria with Renal Failure

Table 1. Differential diagnoses of DUH

\begin{tabular}{lllll}
\hline Disease & Inheritance & Morphology & Location & Associations \\
\hline DUH & AD & $\begin{array}{l}\text { mixture of both hyperpigmented } \\
\text { and hypopigmented macules }\end{array}$ & generalized & $\begin{array}{l}\text { learning difficulty, deafness, } \\
\text { mental retardation, } \\
\text { thrombocytopenia }{ }^{1}\end{array}$ \\
\hline $\begin{array}{l}\text { Dyschromatosis } \\
\text { symmetrica } \\
\text { hereditaria }\end{array}$ & AD & mixture of both hyperpigmented & face, dorsum of \\
and hypopigmented macules & none \\
\hline $\begin{array}{l}\text { Dyschromic } \\
\text { amyloidosis }\end{array}$ & AR & mixture of both hyperpigmented & generalized & none \\
\hline $\begin{array}{l}\text { Xeroderma } \\
\text { pigmentosum }\end{array}$ & AR & $\begin{array}{l}\text { freckle-like hyperpigmentation; } \\
\text { hypo-/hyperpigmentation, } \\
\text { poikiloderma }\end{array}$ & $\begin{array}{l}\text { sun-exposed } \\
\text { areas }\end{array}$ & $\begin{array}{l}\text { skin cancers, photophobia, } \\
\text { keratitis, deafness, mental } \\
\text { retardation }\end{array}$ \\
$\begin{array}{l}\text { Chronic arsenic } \\
\text { toxicity }\end{array}$ & acquired & $\begin{array}{l}\text { guttate hypopigmentation } \\
\text { superimposed on hyperpigmentation }\end{array}$ & $\begin{array}{l}\text { any part of the } \\
\text { body }\end{array}$ & $\begin{array}{l}\text { skin cancers, internal } \\
\text { malignancy }\end{array}$ \\
\hline
\end{tabular}

$\mathrm{AD}=$ Autosomal dominant; $\mathrm{AR}=$ autosomal recessive.

${ }^{1}$ Most of the reported cases had no association, but some reported learning difficulty, deafness, mental retardation or thrombocytopenia $[4,8]$.

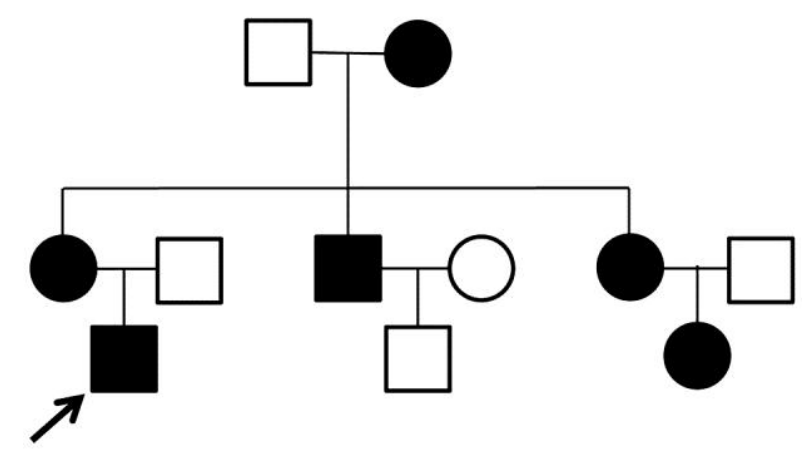

Fig. 1. Family pedigree of the patient which demonstrates autosomal dominant inheritance. 
Case Reports in
Dermatology
Dermatol 2015;7:51-55

DOI: 10.1159/000381174

Rojhiruns

Failure

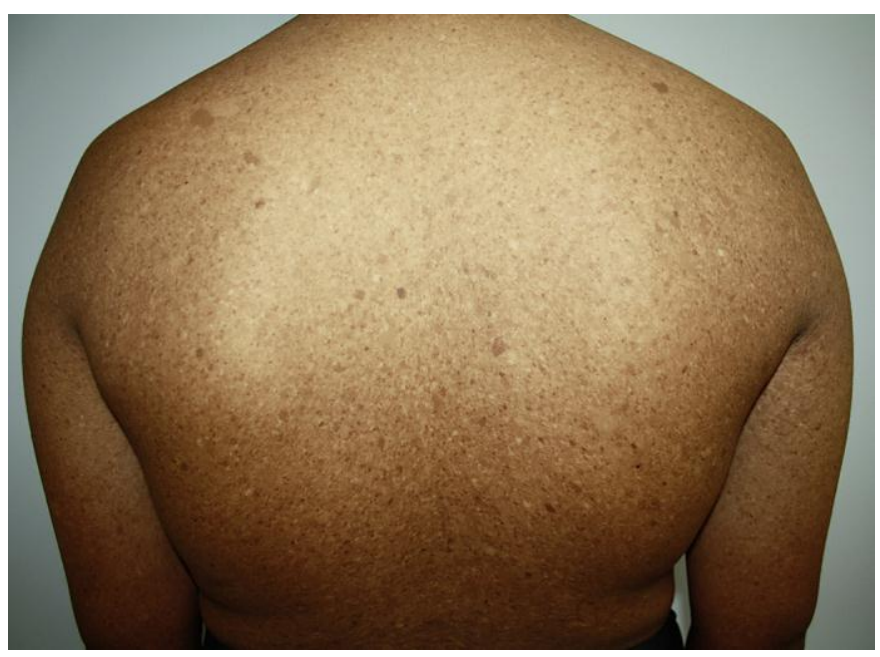

Fig. 2. A mixture of hypopigmented and hyperpigmented macules on the patient's trunk and extremities.

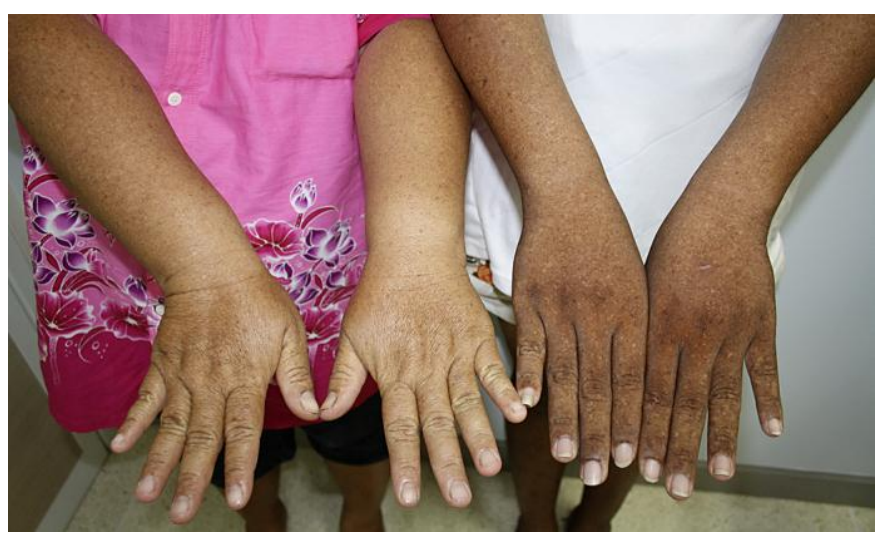

Fig. 3. Clinical characteristics of DUH in the patient (right) and his mother (left). 